\title{
Confocal Microscopy as Useful Tool for Studying Fibrin-Cell Interactions
}

\author{
Rita Marchi and Héctor Rojas \\ Additional information is available at the end of the chapter \\ http://dx.doi.org/10.5772/55586
}

\section{Introduction}

Fibrinogen is a $340 \mathrm{kDa}$ plasma protein that circulates in blood at $2-4 \mathrm{~g} / \mathrm{L}$. It is composed by two set of polypeptide chains: $\mathrm{A} \alpha, \mathrm{B} \beta$, and $\gamma$. Fibrinogen plays diverse roles in coagulation and inflammation. Thrombin is formed after sequential steps of proteases activation, cleaving fibrinogen at the N-terminal of $\mathrm{A} \alpha$ and $\mathrm{B} \beta$ chains. This partially degraded fibrinogen starts to polymerize forming at the end a tridimensional meshwork, the fibrin clot that is further stabilized by the transglutaminase FXIIIa (reviewed in [1]). The fibrin clot together with aggregated platelets form a plug that halt blood extravasation, and simultaneously became a temporal extracellular matrix for wound healing [2] and angiogenesis [3]. Fibrin(ogen) achieve these physiologic functions through its binding to several receptors, integrin and no integrin type, present in platelets $\left(\alpha \mathrm{II}_{\mathrm{b}}-\beta_{3}\right)$, endothelial cells $\left(\alpha_{\mathrm{v}} \beta_{3}\right.$, ICAM- 1 , and VE-cadherin), and leucocytes $\left(\alpha_{\mathrm{M}} \beta_{2}\right.$ and $\left.\alpha_{\mathrm{x}} \beta_{2}\right)$.

Integrins are one of the major families of cell adhesion receptors composed by an $\alpha$ and $\beta$ subunit, non-covalently linked [4]. Both subunits are type I transmembrane proteins, containing large extracellular domains and, in general, a short cytoplasmic domains. Integrin affinities for their extracellular ligands, such as fibronectin, fibrinogen and collagen are regulated by cellular signaling that results in "inside-out" integrin activation. The $\alpha \mathrm{II}_{\mathrm{b}}-\beta_{3}$ and $\alpha_{\mathrm{v}} \beta_{3}$ recognize ligands containing an RGD sequence [5]. Immobilized fibrinogen binds to the platelet receptor $\alpha \mathrm{II}_{\mathrm{b}}-\beta_{3}$ through the sequence $\gamma$ 400-411 (HHLGGAKQAGDV) [6] and to $\alpha_{\mathrm{v}} \beta_{3}$ through the Cterminal part of the A $\alpha$ chain RGD (572-574) [7, 8]. More recently, it has been found that the fibrinogen segment $\gamma$ 365-383 may function as the binding site for $\alpha \mathrm{II}_{\mathrm{b}}-\beta_{3}$ during clot retraction [9], and additionally new fibrinogen $\alpha_{\mathrm{v}} \beta_{3}$ binding sites have been discovered: $\gamma$ 190-202 (GWTVFQKRLDGSV) and $\gamma$ 346-358 (GVYYQGGTYSKAS), and in the $\alpha_{\mathrm{E}}$ (a minor $420 \mathrm{kDa}$ form of fibrinogen, which has a $C$-terminal highly homologous to the $C$ terminal of the $\beta$ and 
$\gamma$ chain). It seems that the $\mathrm{A} \alpha \mathrm{RGD} 572-574$ binds to $\alpha_{\mathrm{v}} \beta_{3}$ at early stage of cell attachment [10]. All these binding sites are inhibited in the presence of the synthetic peptide RGD and antibodies directed against the integrins.

Fibrin(ogen) bridge inflammatory cells to endothelium promoting migration and inflammation by interacting with the leukocyte receptor $\alpha_{\mathrm{M}} \beta_{2}$ and endothelial cell receptor ICAM-1 [11, 12]. Fibrin may also bridge leukocytes to the endothelium through the interaction with the endothelial cell receptor VE-cadherin [13]. The fibrin binding to the non integrin receptor VEcadherin take place at the N-terminal part of fibrin $(\beta 15-42)_{2}$ sequences $[14,15]$ that become exposed after fibrinopeptides B released. Further, it was demonstrated that fibrin promotes the formation of capillaries after binding to VE-cadherin [16].

Several studies have shown that near the endothelial cells surface the fibrin clot is organized into a dense structure, while farther from the cell's surface, at approximately 30 to $50 \mu \mathrm{m}$ the fibrin fibers are looser $[17,18]$. This fibers arrangement proximal to the cells is lost in the presence of antibodies against $\alpha_{\mathrm{v}}$ and/or $\beta_{3}$ integrin subunits [17] or the synthetic RGD peptide [18]. In contrast, other studies have concluded that the fibrin structure near the cell surface was related to the thrombin generated on the cells surface, and in their experiments the addition of RGD peptide did not affect the fibrin structure [19, 20]. They did not add antibodies against the integrin subunits that would be more conclusive.

Dysfibrinogenemias are inherited fibrinogen disorders that affect fibrin(ogen) functions according to the localization of the mutation. The affected patients are diagnosed due to a prolonged thrombin time, decreased functional fibrinogen and normal antigenic levels [21].

Abnormal fibrinogens with mutations located in the integrin/non integrin binding sites have been reported. Fibrinogen Kaiserslautern ( $\gamma$ Lys380Asn) and Osaka V ( $\gamma$ Arg375GLy) had delayed clot retraction and impaired $\alpha \mathrm{II}_{\mathrm{b}}-\beta_{3}$ binding [22, 23]. Fibrinogen Nieuwegein, with a truncated $\mathrm{A} \alpha$ chain (stretch 454-610 deleted), was less supportive for endothelial cells invasion that was related to the abnormal clot structure rather than to the absence of the RGD integrin $\alpha_{\mathrm{v}} \beta_{3}$ binding site ( $\alpha$ 572-574).

In our laboratory we have examined the clot structure of several dysfibrinogenemias near the cell surface of human dermal microvascular endothelial cells (HMEC-1), forming clots with plasma and purified fibrinogen. We have included fibrinogen Caracas I (A $\alpha$ 466-610 deleted) and fibrinogen Caracas V (A $\alpha$ Ser532Cys), with mutations in or near $\alpha$ 572-574, and fibrinogen Caracas VIII (B $\beta$ Tyr41Asn), all of them heterozygous for the mutation. Furthermore, for comparative purposes, clots were formed with fragment $\mathrm{X}$, a degraded form of fibrinogen with around $10 \%$ of $\alpha \mathrm{C}$ domain remaining, and partially degraded $\mathrm{B} \beta$ chain (1-42 residues) [24].

\section{Materials and methods}

\subsection{Fibrinogen coupling to Alexa Fluor ${ }^{\circledR} 488$}

Human plasma fibrinogen was purified in the laboratory by standard protocol [25]. The fibrinogen was coupled to Alexa Fluor $488^{\circledR}$ (Invitrogen, Molecular Probes, Rochester, NY, 
USA) according to manufacturer guidelines. Briefly, purified protein was diluted to $2 \mathrm{mg} / \mathrm{ml}$ with phosphate buffered saline (PBS), and 1M sodium bicarbonate solution was added (1:10). This mixture was transferred to the dye vial, gently mixed and stirred during $1 \mathrm{~h}$ at room temperature. The coupled fibrinogen to Alexa 488 was separated from the uncoupled dye using a column provided by the manufacturer. The absorbance of the conjugate solution was read at 280 and $494 \mathrm{~nm}$ and protein concentration was calculated using the following equation:

Protein concentration $(\mathrm{mg} / \mathrm{ml})=\left[\mathrm{A}_{280}-\left(\mathrm{A}_{494} \times 0.11\right) \times\right.$ dilution factor $] / 1.51$

\subsection{Cell culture and clot assembly}

The human dermal microvascular endothelial cells (HMEC-1) were kindly donated by Dr. Edwin Ades and Mr. Francisco J. Candal of the Centers for Disease Control and Prevention (CDC, Atlanta, GA, USA), and Dr. Thomas Lawley of Emory University (Atlanta, GA, USA). HMEC-1 were cultured in MCDB 131 medium supplemented with $10 \%$ fetal bovine serum, epidermal growth factor $(10 \mathrm{ng} / \mathrm{ml})$, penicillin $(100 \mathrm{U} / \mathrm{ml})$, streptomycin $(100 \mu \mathrm{g} / \mathrm{ml})$, fungizone $0.25 \mu \mathrm{g} / \mathrm{ml}$ and $2 \mathrm{mM} \mathrm{L-glutamine.} \mathrm{Cells}(120,000)$ were seeded in Lab Tek glass chamber slides and maintained at $37{ }^{\circ} \mathrm{C}$ in a humid atmosphere with $95 \%$ air and $5 \% \mathrm{CO}_{2}$ up to reach approximately $80 \%$ confluence. The cells were stained with $4 \mu \mathrm{M}$ di-8-anepps (Invitrogen, Molecular Probes, Rochester, NY, USA) for $15 \mathrm{~min}$ and washed three times with PBS. Apart, $200 \mu \mathrm{l}$ of plasma $(2 \mathrm{mg} / \mathrm{ml}$ fibrinogen concentration) or purified fibrinogen $(1 \mathrm{mg} / \mathrm{ml})$ were mixed with fibrinogen - Alexa $488(95 \mu \mathrm{g} / \mathrm{ml})$, and clotted with a thrombin - $\mathrm{CaCl}_{2}$ solution, 2.7 and $1 \mathrm{nM}$ of human thrombin (American Diagnostica, Greenwich, CT, USA), and $20 \mathrm{mM}$ and $10 \mathrm{mM} \mathrm{CaCl}_{2}$, respectively. The mixture was immediately transferred on the top of the cells. Simultaneously, clots were formed in other wells in the absence of cells. Clot formation was allowed to progress for $2 \mathrm{~h}$ in a tissue culture incubator at $37^{\circ} \mathrm{C}$. Then, the top of the clot was loaded with $200 \mu \mathrm{l}$ of MCDB 131 medium with not supplement.

\subsection{Laser scanning confocal microscopy}

The fibrin clots was observed in a laser scanning confocal microscopy (LSCM) system with 2 lasers, an argon ion laser (488 nm excitation and 515/530 LP filter for emission) and a HeNe laser (543 nm) mounted on one Nikon Eclipse TE 2000-U microscope. The objective used was Plan Apo VC 60X water immersion with a work distance of 0.27 . The acquisition pinhole was set to $60 \mu \mathrm{m}$. The confocal was controlled through the software EZ-C1 from Nikon. The images were acquired with a field of view of $212 \times 212 \mu \mathrm{m}$. A z- and orthogonal 3D projection of $10 \mu \mathrm{m}$ thick $(0.5 \mu \mathrm{m} /$ slice $)$ were done near the cell surface, far from the cell surface (20 to $30 \mu \mathrm{m})$, and without cells, using ImageJ 1.46 and Olympus FV10ASW (version 0.2010404) softwares, respectively. For images analysis, the thickness chosen was $10 \mu \mathrm{m}$ near the cell surface, $5 \mu \mathrm{m}$ at $25 \mu \mathrm{m}$ far from the cell surface, and $10 \mu \mathrm{m}$ without cells. The histogram of the frequency vs intensity (gray scale) of $\mathrm{z}$ projections were calculated with the Olympus FV10ASW (version $0.2010404)$, which gave the number of pixels associated to a gray value $(0-255$; the 0 and the saturation gray values were omitted); these quantities were multiplied and normalized (0-1) using the Origin 8.1 SR2 software, with the following equation: 
$F=\left(F_{0}-F \min \right) /(F \max -F \min )$

F: normalized fluorescence

$\mathrm{F}_{0}$ : frequency of each gray-value

Fmin: frequency of the lowest gray value

Fmax: frequency the highest gray value

The mean of $\mathrm{F}$ was calculated $\left(\mathrm{F}_{\text {mean }}\right)$, and results represented as column graph, $\mathrm{F}_{\text {mean }} \pm \mathrm{SEM}$. Statistical analysis was performed using the t-student, and $p<0.05$ was considered statistically significant.

\section{Results and discussion}

Fibrin clots anchor to different receptors of different cell types through specific fibrin recognition sites present in the three fibrinogen chains. The clot structure changes according to the distance to the cell surface. Near the cell the fibrin density is increased, and pores filling space are smaller compared to greater distance, at approximately $30 \mu \mathrm{m}$. This particular fibrin architecture is related to the presence of cells since when clots were formed in its absence the clot structure was uniform, resembling that observed far from the cell surface. The figure 1 shows the column graph of the $\mathrm{F}_{\text {mean }}$ for Alexa 488 of clots performed with plasma, and figure 2 for clots done with purified fibrinogen. For patients and controls, the fluorescence intensity was greater near the cell surface compared to that far from it, and without the presence of cells, which were statistically significant at $p<0.05$. Furthermore, fibrinogens Caracas I, Caracas V, and Caracas VIII had less fluorescence near the cell surface compared to their respective controls $(p<0.05)$.

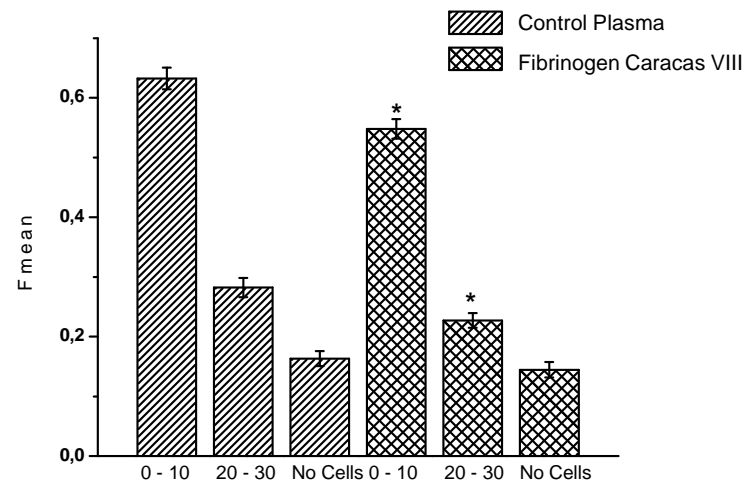

Figure 1. Column graph of Alexa 488-fibrin fluorescence of clot done with plasma. The first and second column of Control plasma and Fibrinogen Caracas VIII represent the distance from the cell surface in $\mu \mathrm{m} .{ }^{*} p<0.05$. 


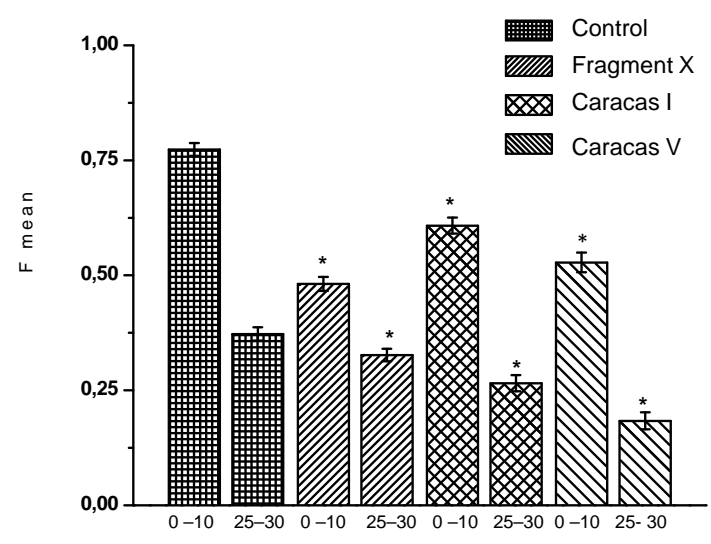

Figure 2. Column graph of Alexa 488-fibrin fluorescence of clot done with purified fibrinogen. The first and second column of each sample represents the distance from the cell surface in $\mu \mathrm{m}$. ${ }^{*} p<0.05$, compared to control.

The figure 3 shows a $\mathrm{Z}$ projection of the region close to the cell surface, $10 \mu \mathrm{m}$ thick, when clots were formed with plasma (figure 3a), with purified fibrinogen (figure 3b), and with fibrinogen fragment $X$ (figure $3 c$ ). The fields where fibers interacted with cell receptors are brighter compared to that without interactions. Clots formed with plasma and purified fibrinogen had 1.3 and 1.6 times more interaction with the cell surface compared to fragment $X$, differences statistically significant. It was common to observe stressed fibers as consequence of fibrin binding to cell receptors (signaled with arrow in figure $3 b$ ). The interaction of purified fibrinogen with cells was approximately 1.2 times higher than plasma $(\mathrm{p}<0.05)$. Although plasma had more fibrinogen (0.4 mg total) compared to purified fibrinogen $(0.2 \mathrm{mg})$, the presence of other proteins that compete with fibrin for receptor binding, mainly fibronectin and vitronectin, could decrease fibrin interaction. 


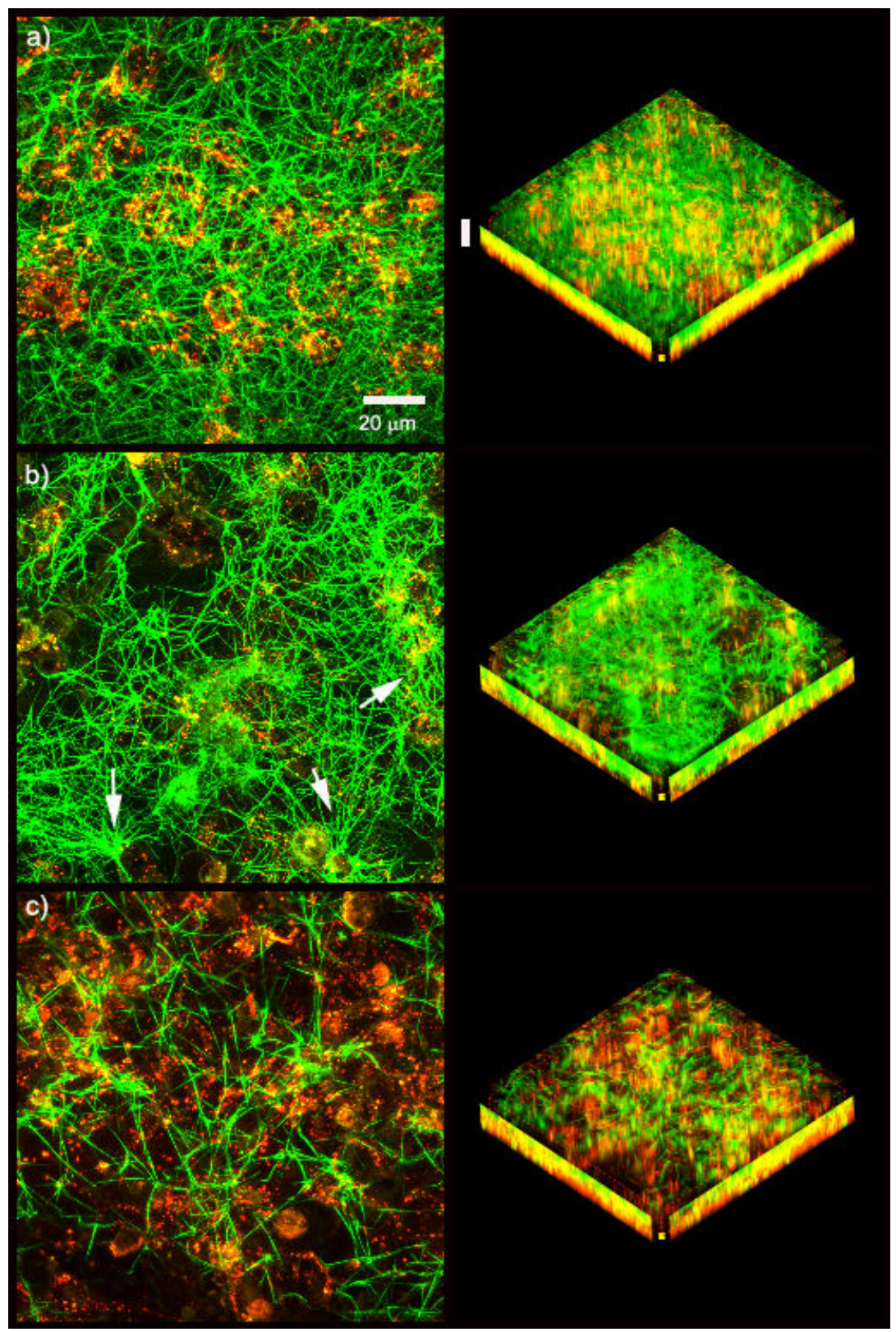

Figure 3. Z- projection of control fibrin clots performed on the top of HMEC-1 cells. Fibrin was labeled with Alexa 488 (green), and cells with di- 8-anepps (red). The thickness of each clot corresponded to $10 \mu \mathrm{m}$ (from the bottom of the dish). a) Control plasma, b) Normal purified fibrinogen, c) Fibrinogen Fragment X. Next to each Z projection is shown the orthogonal 3D projection. The vertical bar represents $10 \mu \mathrm{m}$. 
When $\mathrm{Z}$ projections were done farther from the cell surface (from 20 to $30 \mu \mathrm{m}$ ), figure 4 , the fibrin structure became more homogeneous, the fibrin density decreased and the pores filling space were larger both in plasma (figure $4 \mathrm{a}$ ) and purified fibrinogen clots (figure $4 \mathrm{~b}$ ), similar to what was observed when clots were formed without cells (figure $4 \mathrm{~d}$ and $4 \mathrm{e}$ ); however, the appearance of the fragment $X$ - fibrin almost did not change (figure $4 \mathrm{c}$ ), similar to the condition without cells (compare figure $3 \mathrm{c}$ with $4 \mathrm{c}$ and $4 \mathrm{f}$ ).

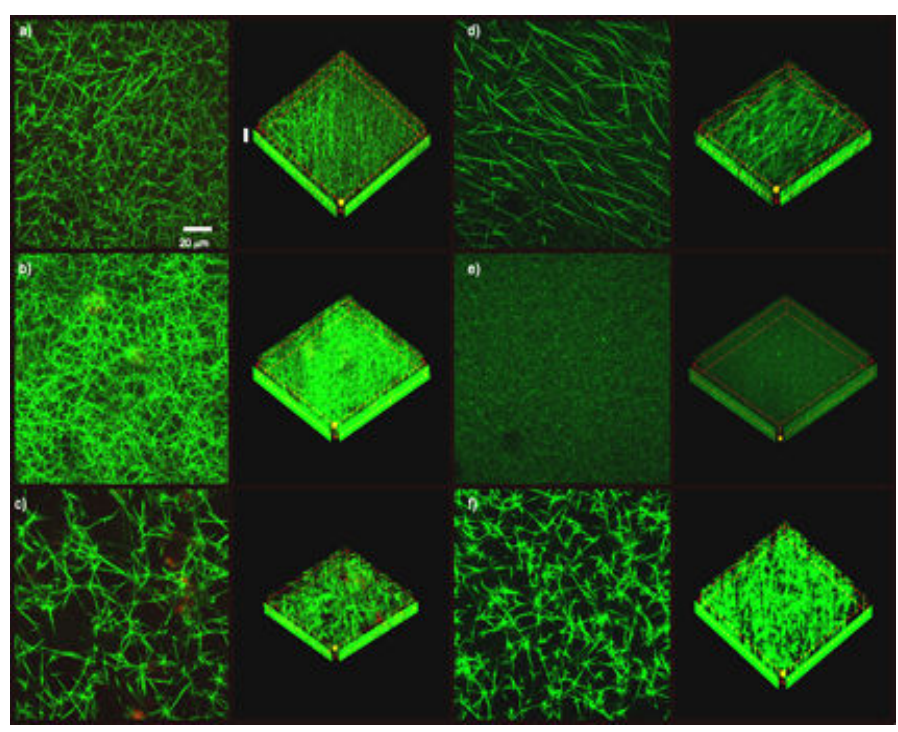

Figure 4. Z projection of control fibrin network located at 20 to $30 \mu \mathrm{m}$ from the cell surface, and of clots performed in the absence of cells. Fibrin was labeled with Alexa 488 (green), and cells with di-8-anepps (red). The cells were not visualized at this distance. a) Control plasma, b) Normal purified fibrinogen, c) Fibrinogen Fragment X. Clots without cells: d) Control plasma, e) Normal purified fibrinogen, f) Fibrinogen Fragment X. Next to each Z projection is shown the orthogonal 3D projection. The vertical bar represents $10 \mu \mathrm{m}$.

Our results confirmed previous work performed by Jerome et al [17]. Other authors have found that the clot organization was related to the thrombin generated on the cell surface, and when they added exogenous thrombin no change was observed in the fibrin morphology [19].

In order to study the effect of certain fibrinogen mutations on fibrin organization on the cell surface, we have chosen dysfibrinogenemias with mutations in or close to the $\alpha_{\mathrm{V}} \beta_{3}$ integrin binding site ( $\alpha 572-574)$ : fibrinogen Caracas I (A $\alpha$ Ser466Stop) and Caracas V (A $\alpha$ Ser532Cys); and in the VE-Cadherin binding site (B $\beta 15-66)_{2}$ [26]: fibrinogen Caracas VIII (B $\beta$ Tyr41Asn).

Fibrinogen Caracas I and V formed tight clots composed by very thin fibers (figure 5 and 6). The figure 2 shows that fibrin Caracas I and V have less interaction with the receptors of HMEC-1 compared to control (1.3 and 1.5, respectively). The fibrin architecture near the cell surface is shown in figure $5 \mathrm{a}$ (Caracas I) and $5 \mathrm{~b}$ (Caracas V). This pattern was lost far from the cell surface, similar to that without cells (figure $6 \mathrm{a}$ and $6 \mathrm{~b}$, and $6 \mathrm{~d}$ and $6 \mathrm{e}$, respectively). Both 
fibrinogen Caracas I and V have decreased interaction to the $\alpha_{\mathrm{v}} \beta_{3}$ receptor, due to that fibrinogen Caracas I has decreased population of fibrinogen molecules with $\alpha 572-574$, while the point mutation of Caracas V at $\alpha$ Ser532 probably is closer to the integrin binding site.

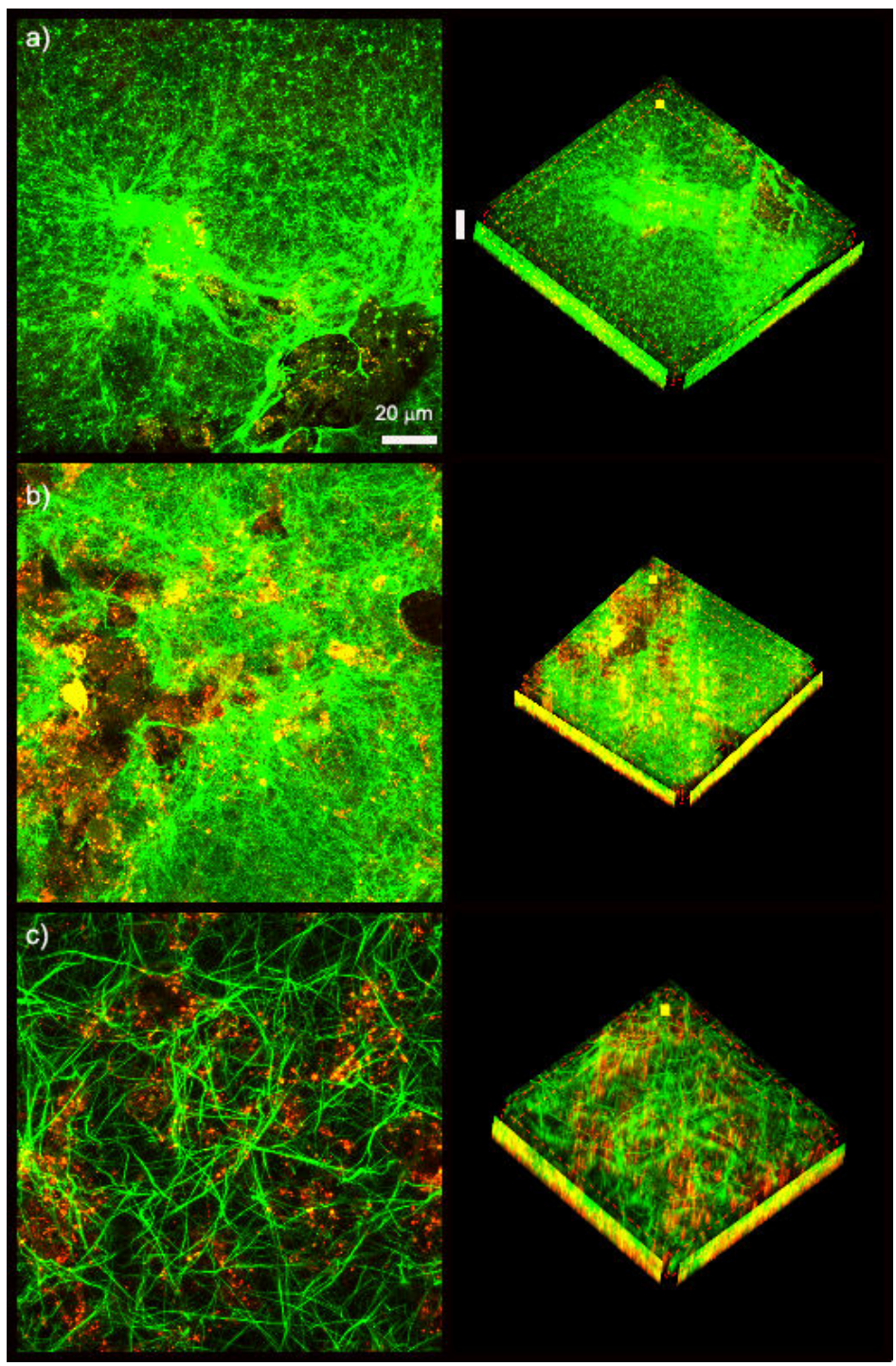

Figure 5.Z-projection of fibrin clots of dysfibrinogenemic patients performed on the top of HMEC-1 cells. Fibrin was labeled withAlexa 488 (green), and cells with di-8-anepps(red). The thickness of each clot corresponded to $10 \mu \mathrm{m}$ (from the bottom of the dish). a) Purified fibrinogen Caracas I, b) Purified fibrinogen Caracas V, and c) Plasma from fibrinogen Caracas VIII. Next to each Z projection is shown the orthogonal3D projection. The vertical bar represents $10 \mu \mathrm{m}$. 
The clinical implications of these results are far to be understood, while fibrinogen Caracas I outcome was mild bleeder, fibrinogen Caracas V was thrombotic. It is more likely that less interaction of the thrombus with the endothelium would embolize the vessel blood, since less adhesion could imply that the force needed to sweep it away are less. Fibrinogen Caracas V had pulmonary embolism but not Caracas I. If there is a threshold value, since fibrinogen Caracas $\mathrm{V}$ had less interaction, is subject of future investigation.

The fibrin network of fibrinogen Caracas VIII was done with plasma. The meshwork was composed by thick fibers and large pores (figure 5 and 6). The interaction of patient's fibers with the cell receptors was approximately 1.2 times less than control plasma (figure 1); in spite the fact that the $\mathrm{C}$-terminal region of the $\alpha$-chain was normal. The figure $5 \mathrm{c}$ shows fibrin Caracas VIII organization on the cell surface, compared to fibrinogen Caracas I and V, the fibrin density around the cells was very decreased. The architecture of Caracas VIII fibrin far from the cell surface was similar to that performed without cells (figure $6 \mathrm{c}$ and $6 \mathrm{f}$, respectively).

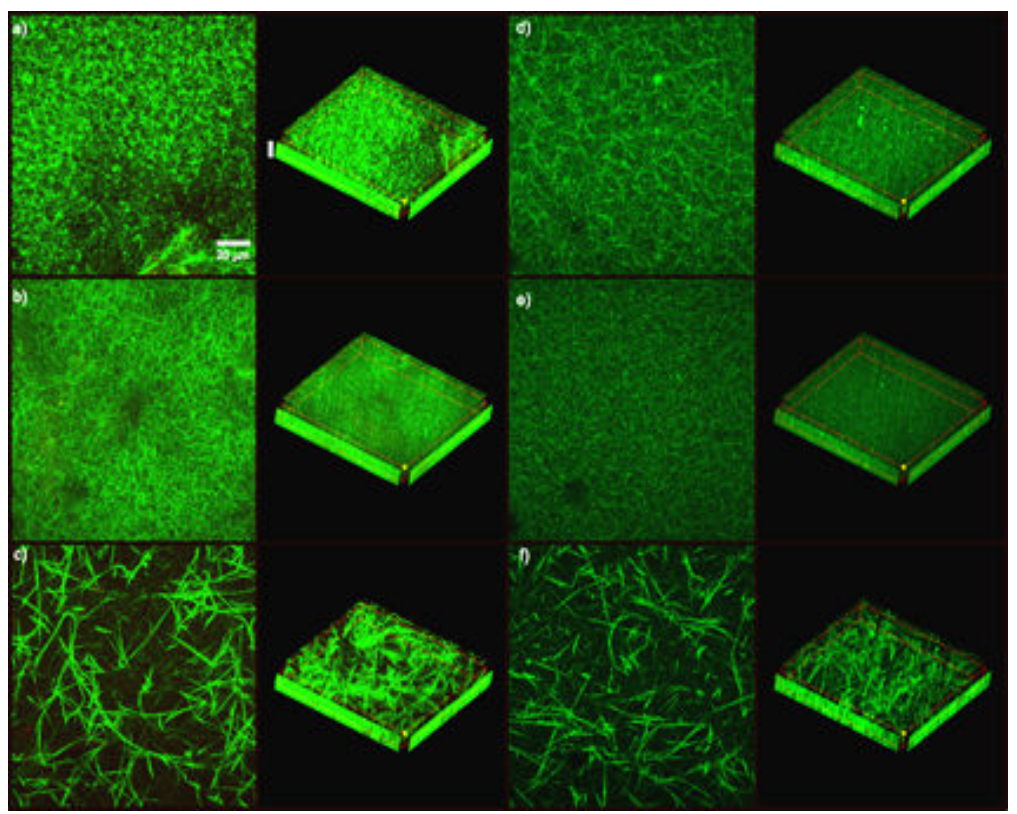

Figure 6. Z projection of dysfibrinogenemic fibrin network located at 20 to $30 \mu \mathrm{m}$ from the cell surface, and of clots performed in the absence of cells. Fibrin was labeled with Alexa 488 (green), and cells with di- 8-anepps (red). The cells were not visualized at this distance. a) Purified fibrinogen Caracas I, b) Purified fibrinogen Caracas V, and c) Plasma from fibrinogen Caracas VIII. Clots without cells: d) Purified fibrinogen Caracas I, e) Purified fibrinogen Caracas V, and f) Plasma from fibrinogen Caracas VIII. Next to each Z projection is shown the orthogonal 3D projection. The vertical bar represents $10 \mu \mathrm{m}$.

One possible explanation is that fiber thickness influence the quantity of ligands per unit of fibrin surface. This would partially explain why Fibrinogen Caracas VIII with normal $\alpha \mathrm{C}$ had less interaction with the cells. The contribution of fibrin binding to VE-cadherin to fibrin 
organization is less clear, since the VE-cadherin contributes to cell-cell and not to cell-extracellular matrix interaction [27].

Fibrinogen Caracas VIII was asymptomatic, and the fibrinolysis process was much faster compared to the above mentioned fibrinogens. Probably this abnormal fibrinogen is protected against embolization due to the fast lysis rate.

The fibrin formed with fibrinogen fragment $\mathrm{X}$ had approximately $90 \%$ less $\alpha \mathrm{C}$ domains and degraded N-terminal $B \beta$ chain, and the least interaction with the cell surface, highlighting the importance of the $\alpha 572-574$ for fibrin organization on the cell surface.

In summary, these preliminary data indicated that the fibrin structure is important for its interaction with cell receptors and that the $\alpha 572-574$ stretch seemed to be the main responsible of fibrin organization on cell surface.

\section{Acknowledgements}

We are grateful to Dr. Edwin Ades and Mr. Francisco J. Candal of the Centers for Disease Control and Prevention, and Dr. Thomas Lawley of Emory University (Atlanta, GA, USA) for the donation of the human microvascular endothelial cells (HMEC-1). We want to thank M.Sc. Jenny Dimelza Gómez from the University of Pamplona of Colombia for the fragment $X$ preparation.

\section{Author details}

Rita Marchi ${ }^{1}$ and Héctor Rojas ${ }^{2}$

*Address all correspondence to: rmarchi@ivic.gob.ve

1 Venezuelan Research Institute, Experimental Medicine Department, Caracas, Venezuela

2 Immunology Institute, Central University of Venezuela, Caracas, Venezuela

\section{References}

[1] Stief, T. W. ed. Fibrinogen and Fibrin: structure and functional aspects., ed. R. Marchi. (2012). NOVA.

[2] Laurens, N, Koolwijk, P, \& De Maat, M. P. Fibrin structure and wound healing. Journal of thrombosis and haemostasis, (2006). , 932-939. 
[3] Van Hinsbergh, V. W, Collen, A, \& Koolwijk, P. Role of fibrin matrix in angiogenesis. Annals of the New York Academy of Sciences, (2001). , 426-437.

[4] Hynes, R. O. Integrins: bidirectional, allosteric signaling machines. Cell, (2002). , 673-687.

[5] Humphries, J. D, Byron, A, \& Humphries, M. J. Integrin ligands at a glance. Journal of cell science, (2006). Pt 19): , 3901-3903.

[6] Kloczewiak, M, et al. Platelet receptor recognition site on human fibrinogen. Synthesis and structure-function relationship of peptides corresponding to the carboxy-terminal segment of the gamma chain. Biochemistry, (1984). , 1767-1774.

[7] Cheresh, D. A, et al. Recognition of distinct adhesive sites on fibrinogen by related integrins on platelets and endothelial cells. Cell, (1989). , 945-953.

[8] Smith, J. W, et al. Interaction of integrins alpha v beta 3 and glycoprotein IIb-IIIa with fibrinogen. Differential peptide recognition accounts for distinct binding sites. The Journal of biological chemistry, (1990). , 12267-12271.

[9] Podolnikova, N. P, et al. Identification of a novel binding site for platelet integrins alpha IIb beta 3 (GPIIbIIIa) and alpha 5 beta 1 in the gamma C-domain of fibrinogen. The Journal of biological chemistry, (2003). , 32251-32258.

[10] Smith, R. A, et al. Evidence for new endothelial cell binding sites on fibrinogen. Thrombosis and haemostasis, (2000). , 819-825.

[11] Altieri, D. C. Regulation of leukocyte-endothelium interaction by fibrinogen. Thrombosis and haemostasis, (1999). , 781-786.

[12] Languino, L. R, et al. Fibrinogen mediates leukocyte adhesion to vascular endothelium through an ICAM-1-dependent pathway. Cell, (1993). , 1423-1434.

[13] Petzelbauer, $\mathrm{P}$, et al. The fibrin-derived peptide Bbeta15-42 protects the myocardium against ischemia-reperfusion injury. Nature Medicine, (2005). , 298-304.

[14] Bach, T. L, et al. Endothelial cell VE-cadherin functions as a receptor for the beta15-42 sequence of fibrin. The Journal of biological chemistry, (1998). , 30719-30728.

[15] Gorlatov, S, \& Medved, L. Interaction of fibrin(ogen) with the endothelial cell receptor VE-cadherin: mapping of the receptor-binding site in the NH2-terminal portions of the fibrin beta chains. Biochemistry, (2002). , 4107-4116.

[16] Martinez, J, et al. Interaction of fibrin with VE-cadherin. Annals of the New York Academy of Sciences, (2001). , 386-405.

[17] Jerome, W. G, Handt, S, \& Hantgan, R. R. Endothelial cells organize fibrin clots into structures that are more resistant to lysis. Microscopy and microanalysis : the official journal of Microscopy Society of America, Microbeam Analysis Society, Microscopical Society of Canada, (2005). , 268-277. 
[18] Marchi, R, et al. Structure of fibrin network of two abnormal fibrinogens with mutations in the alphaC domain on the human dermal microvascular endothelial cells 1 . Blood coagulation \& fibrinolysis : an international journal in haemostasis and thrombosis, (2011). , 706-711.

[19] Campbell, R. A, et al. Cellular procoagulant activity dictates clot structure and stability as a function of distance from the cell surface. Arteriosclerosis, thrombosis, and vascular biology, (2008). , 2247-2254.

[20] Campbell, R. A, et al. Contributions of extravascular and intravascular cells to fibrin network formation, structure, and stability. Blood, (2009). , 4886-4896.

[21] Hill, M, \& Dolan, G. Diagnosis, clinical features and molecular assessment of the dysfibrinogenaemias. Haemophilia : the official journal of the World Federation of Hemophilia, (2008). , 889-897.

[22] Ridgway, H. J, et al. Fibrinogen Kaiserslautern (gamma 380 Lys to Asn): a new glycosylated fibrinogen variant with delayed polymerization. British journal of haematology, (1997). , 562-569.

[23] Yoshida, N, et al. Characterization of an abnormal fibrinogen Osaka V with the replacement of gamma-arginine 375 by glycine. The lack of high affinity calcium binding to D-domains and the lack of protective effect of calcium on fibrinolysis. The Journal of biological chemistry, (1992). , 2753-2759.

[24] Marder, V. J, \& Budzynski, A. Z. The structure of the fibrinogen degradation products. Progress in hemostasis and thrombosis, (1974). , 141-174.

[25] Jacobsen, E. K.P., A modified beta-alanine precipitation procedure to prepare fibrinogen free of antithrombin III and plasminogen. Thrombosis research, (1973). , 145-148.

[26] Yakovlev, S, \& Medved, L. Interaction of fibrin(ogen) with the endothelial cell receptor VE-cadherin: localization of the fibrin-binding site within the third extracellular VE-cadherin domain. Biochemistry, (2009). , 5171-5179.

[27] Alghisi, G. C, Ponsonnet, L, \& Ruegg, C. The integrin antagonist cilengitide activates alphaVbeta3, disrupts VE-cadherin localization at cell junctions and enhances permeability in endothelial cells. PLoS One, (2009). , e4449. 